\title{
Engineering properties of controlled low strength material (CLSM) incorporating red mud
}

Tan Manh Do and Young-sang Kim ${ }^{*}$

*Correspondence:
geoyskim@jnu.ac.kr
Department of Civil
and Environmental
Engineering, Chonnam
National University,
Yeosu 550-749, South Korea

${ }^{*}$ Correspondence: geoyskim@jnu.ac.kr and Environmental National University, Yeosu 550-749, South Korea

\begin{abstract}
Background: Controlled low strength materials (CLSM), known as flow able fill is used as a replacement of compacted soil in cases where the application of the latter is difficult or impossible. The low mechanical requirements compared with concrete enable the use of industrial wastes for the production of CLSM. In general, CLSM mixtures consist of standard materials such as Portland cement, fly ash, fine aggregate and water. However, other industrial by-products and recycled materials are also accepted and encouraged as long as they are considered to be available, cost-effective for specific application and the necessary characteristics of the mixture such as flowability, strength, excavatability, and density are acceptable.
\end{abstract}

Methods: The aim of this study is to evaluate the feasibility of incorporating red mud as a partial replacement for Portland cement into a controlled low-strength material (CLSM) made by industrial by-products (e.g., ponded ash and fly ash). A control mixture was initially produced with ponded ash, Portland cement, Class F fly ash, and water. For other mix proportions, red mud was substituted for Portland cement in amounts of 5, $10,15,20,25$, and $30 \%$ by weight. The bleeding, flowability, fresh density, initial setting time of fresh CLSM mixtures were measured and the follows were hardened ones including compressive strength, corrosivity.

Results: Expectedly, all general properties of CLSM incorporating red mud did fall within the acceptable ranges. They performed well and conformed to the requirements of CLSM in ACl 229 standards with regard to flowability, bleeding rate, initial setting time, corrosivity and unconfined compressive strength.

Conclusions: The partial replacement of cement by red mud, possibly up to $30 \%$ in mixtures, would reduce flowability and slightly increase corrosivity evidenced by $\mathrm{pH}$ but still meet the requirements. Especially, it was found that an increase in red mud content could lead to an improvement in the stability (bleeding rate) and accelerate the setting process on the performances of the proposed CLSM. Finally, with regard to strength at 28 days, CLSM with highest strength could be produced by an optimum replacement of $15 \%$ red mud to cement. In overall, it is worth noting that red mud could be feasible and potential in use as a partial replacement to Portland cement in CLSM production.

Keywords: CLSM, Red mud, Industrial by-products, Engineering properties

\section{Background}

The American Concrete Institute (ACI) defines a CLSM as a self-leveling, self-compacting, and cementitious material primarily used to replace conventional backfill soil and

(c) 2016 Do and Kim. This article is distributed under the terms of the Creative Commons Attribution 4.0 International License (http://creativecommons.org/licenses/by/4.0/), which permits unrestricted use, distribution, and reproduction in any medium, provided you give appropriate credit to the original author(s) and the source, provide a link to the Creative Commons license, and indicate if changes were made. 
structural fillings that result in unconfined compressive strengths of $1200 \mathrm{psi}(8.3 \mathrm{MPa})$ or less [2]. CLSM should not be considered as a type of low-strength concrete, but rather as a structural backfill. CLSM is known by many different names such as flowable fill, controlled density fill, unshrinkable fill, flowable mortar, soil-cement slurry, and plastic soil-cement. There are various inherent advantages of using CLSM instead of compacted fill in these applications. These benefits include reduced labor and equipment costs (due to self-leveling properties and no need for compaction), faster construction, and the ability to place material in confined spaces [2]. If future excavation is anticipated, the maximum long-term compressive strength should generally be less than $2.1 \mathrm{MPa}$ (i.e., general fill) [2]. It is advantageous due to the relatively low strength itself of CLSM. Another advantage of CLSM is that it possibly contains by-product materials, thereby reducing the demand on landfills, where these materials may otherwise be deposited and contributing towards the sustainable development [32]. In general, CLSM mixtures consist of standard materials such as Portland cement, fly ash, fine aggregate and water. However, other industrial by-products and recycled materials are also accepted and encouraged as long as they are considered to be available, cost-effective for specific application and the necessary characteristics of the mixture such as flowability, strength, excavatability, and density are acceptable [2].

Recently, many studies have been performed regarding the use of various industrial by-products and recycled materials in the production of CLSM. Several successful applications of using fly ash in CLSM production have been addressed due to its advantages of good flowability, reduced segregation and reduce material cost $[8,9,14,18,24,27$, 37]. Bottom ash was a favourite by-product employed in the production of CLSM as a fine aggregate [14, 21, 22, 31, 32]. Lachemi et al. [16, 17], Pierce et al. [28] have all developed CLSM using Cement kiln dust due to the smaller amount of lime and silica present in CKD that can be effectively added to produce a very low-strength material. A large amount of by-product foundry sand was incorporated in CLSM due to its lower cost and availability $[4,39,41,36]$. Various other industrial by-products and recycled materials such as flue gas desulfurization (FGD) [5], oyster shell [15], scrap tire rubber [26], recycled glass [25], acid mine drainage (AMD) sludge [9], blast furnace slag [17, 20], recycled concrete [1], clean coal ash [23] were also utilized in CLSM production.

Meanwhile, due to the continuous development of the alumina industry, a huge amount of red mud which is the by-product of the manufacture of alumina from bauxite by the Bayer process is annually generated in Korea with a rate of 200,000 tons/year [19]. Red mud is a complex material whose chemical and mineralogical composition varies widely, depending upon the source of bauxite and the technological process parameters. It contains six major constituents, namely $\mathrm{Fe}_{2} \mathrm{O}_{3}, \mathrm{Al}_{2} \mathrm{O}_{3}, \mathrm{SiO}_{2}, \mathrm{TiO}_{2}, \mathrm{Na}_{2} \mathrm{O}$ and $\mathrm{CaO}$ and small quantities of numerous minor/trace elements (as oxides) such as $\mathrm{V}, \mathrm{Ga}$, $\mathrm{Cr}, \mathrm{P}, \mathrm{Mn}, \mathrm{Cu}, \mathrm{Cd}, \mathrm{Ni}, \mathrm{Zn}, \mathrm{Pb}, \mathrm{Mg}, \mathrm{Zr}, \mathrm{Hf}, \mathrm{Nb}, \mathrm{U}, \mathrm{Th}, \mathrm{K}, \mathrm{Ba}, \mathrm{Sr}$, rare earths, etc. Every red mud is composed of as many as 14-21 mineral phases [19]. It is generally discharged as highly alkaline slurry ( $\mathrm{pH} 10-13.5)$ with $15-40 \%$ solids, which is pumped away for appropriate disposal [43]. The disposal of this alkaline waste sludge is expensive (i.e., up to $1-2 \%$ of the alumina price), as it requires a lot of land and causes a number of environmental problems [11]. During the past decades, extensive work has been done by many researchers to develop various economic ways for the utilization of red mud 
in the production of constructional materials that enable a potentially high consumption rates. As an alternative to traditional raw materials used in brick production, red mud utilization not only reduces the cost of raw materials, but also has great environmental significance [3]. For the purpose of stabilization material, Kalkan [13] presented an experimental program with various compacted clay samples containing red mud and cement-red mud additives. The results showed a high compressive strength, a decrease in hydraulic conductivity and swelling as compared to natural clay samples. It was concluded that red mud and cement-red mud materials can be successfully used for the stabilization of clay liners in geotechnical applications. The potential use of red mud in the production of special cements (e.g., red mud cement, iron rich cement) was suggested and reviewed in the literatures [30,38]. Other applications of using red mud in constructional materials such as geo-polymers [7, 10], ceramics and tiles [34, 44], road base material [46] were also addressed in the previous studies. However, until recently, there was no investigation that addressed the economically feasible use of red mud in the production of CLSM. The reactions of pozzolanic materials (e.g., fly ash and ponded ash in CLSM mixture) in high alkaline environment due to the presence of red mud are believed to help hardening and strength development of CLSM. The aim of the present work was to evaluate the feasibility of the red mud utilization in the production of a CLSM made by industrial by-products throughout its engineering properties.

\section{Experimental program}

Materials

Generally, fine aggregate provides the solids to develop strength as well as load carrying capacity of CLSM. Fine aggregate is considered as a material with particles in a size range from $4.75 \mathrm{~mm}$ (No. 4 sieve) to $0.075 \mathrm{~mm}$ (No. 200 sieve), commonly up to $80-85 \%$ [35]. In the present study, ponded ash originated from cogeneration plants in Honam area (South Korea) was used as a fine aggregate in a production of CLSM. Ponded ash was first dried in an oven at $105^{\circ} \mathrm{C}$ until constant weight, and then sieved through a $9.52 \mathrm{~mm}$ size sieve to eliminate unnecessary large particles and approach the particle size of natural fine aggregates. The physical properties of ponded ash are detailed in Table 1. The particle size distribution curve of ponded ash is shown in Fig. 1. Soil classification parameters based on Unified Soil Classification System (USCS) are summarized in Table 2. The fineness modulus of ponded ash was 3.37. In addition to fine aggregate, other ingredients such as cement, supplementary cementitious materials and water are also important in

Table 1 Physical properties of ponded ash

\begin{tabular}{ll}
\hline Properties & Ponded ash \\
\hline Maximum dry density $\left(\mathrm{kg} / \mathrm{m}^{3}\right)$ & 1279 \\
Optimum moisture content $(\mathrm{OMC})(\%)$ & 17 \\
Natural water content (\%) & 15.57 \\
Specific gravity & 2.15 \\
Water absorption (\%) & 4.65 \\
Fineness modulus & 3.37 \\
Particles $<75 \mu m(\%)$ & 4.91 \\
Color & Black \\
\hline
\end{tabular}




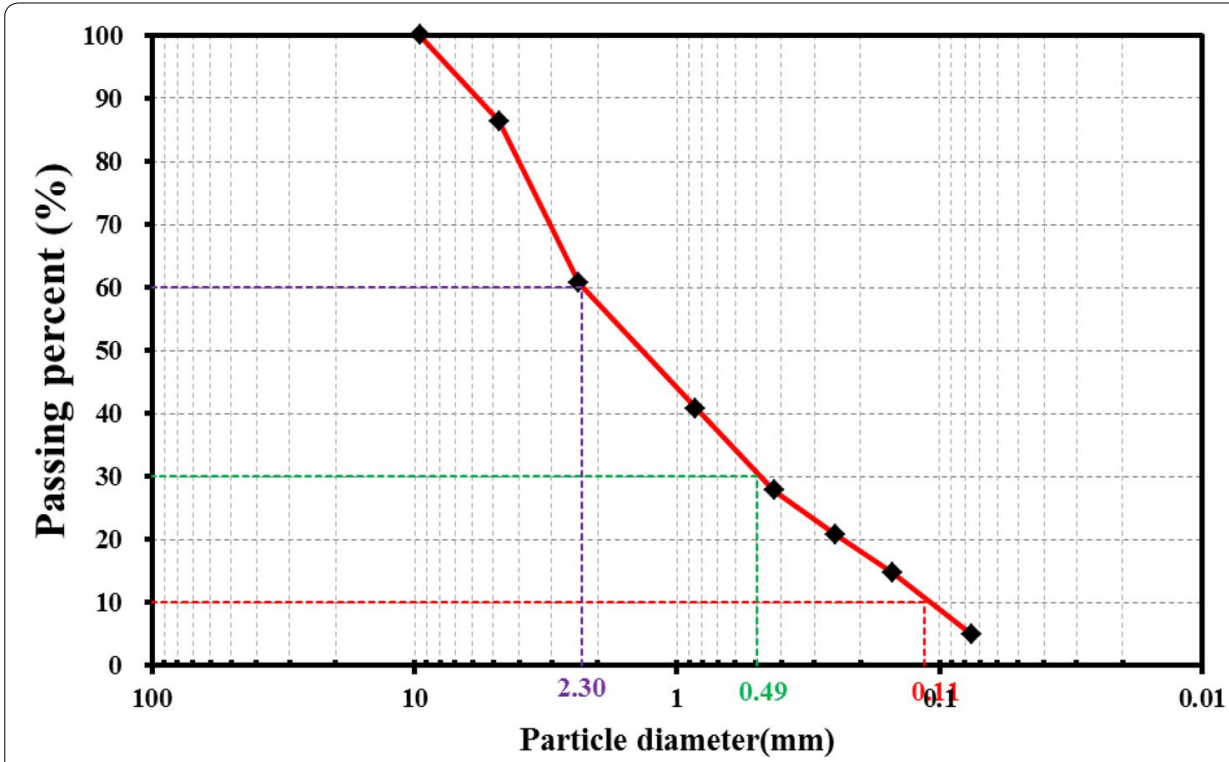

Fig. 1 Particle size distribution of ponded ash

CLSM mixtures with the hydration process that enables CLSM to be cohesive and hence harden to develop strength. In this study, Ordinary type I Portland cement conforming to ASTM C 150 was employed. Fly ash used in CLSM can improve the fluidity or flowability of mixtures with its fineness and spherical shaped particles. Bleeding of free water is reduced by using fly ash because of the increase of solids and therefore less segregation of the solids [9]. In this study, Class F fly ash produced from Cogeneration plant in Honam area (South Korea) conforming to ASTM C 618 was used with its specific gravity of 2.3. The chemical composition of fly ash is listed in Table 3. The red mud collected from Bayer process in Honam area (South Korea) was used in this investigation. The specific surface area (Ss) of red mud used in this study was $15.90 \mathrm{~m}^{2} / \mathrm{g}$, which is much higher than that of cement $\left(\mathrm{Ss}_{\text {cement }}=1.22 \mathrm{~m}^{2} / \mathrm{g}\right)$. The geotechnical properties of red mud with specific gravity (3.15), liquid limit $(\mathrm{LL}=46.6)$, plastic index $(\mathrm{PI}=7.63)$, compaction characteristics $\left(\mathrm{OMC}=34.4 \%, \mathrm{MDD}=1.415 \mathrm{~g} / \mathrm{cm}^{3}\right)$, permeability $\left(2.35 \times 10^{-6} \mathrm{~cm} / \mathrm{s}\right)$, and California bearing ratio $(15.4 \%)$ were determined in this experiment. A much higher specific gravity of red mud than that of normal soil was obtained primarily due to the presence of iron rich minerals in red mud. The main problem of this waste is its high $\mathrm{pH}$ value (11.6-12.2). The particle size distributions of fly ash, cement and red mud (RM) are given in Fig. 2. RM has smaller particle sizes than both cement and fly ash. The X-ray fluorescence (XRF) MiniPal 2/PANanalytical (The Netherlands) was used to determine the chemical compositions of the all raw materials shown in Table 3.

Table 2 Soil classification parameters

\begin{tabular}{llllllll}
\hline Soil type & \multicolumn{6}{l}{ Soil classification parameters } \\
\cline { 2 - 7 } & $\mathbf{D}_{\mathbf{1 0}}(\mathbf{m m})$ & $\mathbf{D}_{\mathbf{3 0}}(\mathbf{m m})$ & $\mathbf{D}_{\mathbf{6 0}}(\mathbf{m m})$ & $\mathbf{C}_{\mathbf{u}}$ & $\mathbf{C}_{\mathbf{c}}$ & Fineness modulus & USCS \\
\hline Ponded ash & 0.11 & 0.49 & 2.30 & 20.25 & 0.94 & 3.37 & $\mathrm{SP}$ \\
\hline
\end{tabular}

$D_{10}, D_{60}, D_{30}$ refer particle diameter such that 10,60 and $30 \%$ correspondingly of the soil grain are smaller than this size; $C_{u}$ refers the coefficient of uniformity; $C_{c}$ refers the coefficient of curvature; SP refers a poorly graded sand 
Table 3 Chemical compositions of ponded ash, fly ash, cement and RM by weight (\%)

\begin{tabular}{lllll}
\hline Compound & PA & FA & Cement & RM \\
\hline $\mathrm{CaO}$ & 1.80 & 1.99 & 64.35 & 7.10 \\
$\mathrm{SiO}_{2}$ & 62.53 & 56.88 & 17.16 & 15.12 \\
$\mathrm{Al}_{2} \mathrm{O}_{3}$ & 20.91 & 21.52 & 3.57 & 19.87 \\
$\mathrm{SO}_{3}$ & - & - & 2.20 & 0.72 \\
$\mathrm{MgO}$ & 0.69 & 0.92 & 2.66 & 0.37 \\
$\mathrm{Fe}_{2} \mathrm{O}_{3}$ & 8.70 & 6.34 & 4.03 & 22.21 \\
$\mathrm{TiO}_{2}$ & 1.28 & 1.21 & 0.29 & 5.24 \\
$\mathrm{~K}_{2} \mathrm{O}$ & 1.58 & 1.11 & 0.11 \\
$\mathrm{Na}_{2} \mathrm{O}$ & 1.44 & 0.49 & - & 14.92 \\
$\mathrm{MnO}$ & 0.39 & 0.06 & 0.20 & - \\
$\mathrm{P}_{2} \mathrm{O}_{5}$ & 0.09 & - & 0.14 & 0.09 \\
$\mathrm{ZnO}$ & - & 0.03 & 0.17 & - \\
Loss of ignition & 0.01 & 8.73 & 3.93 & 13.68 \\
\hline
\end{tabular}

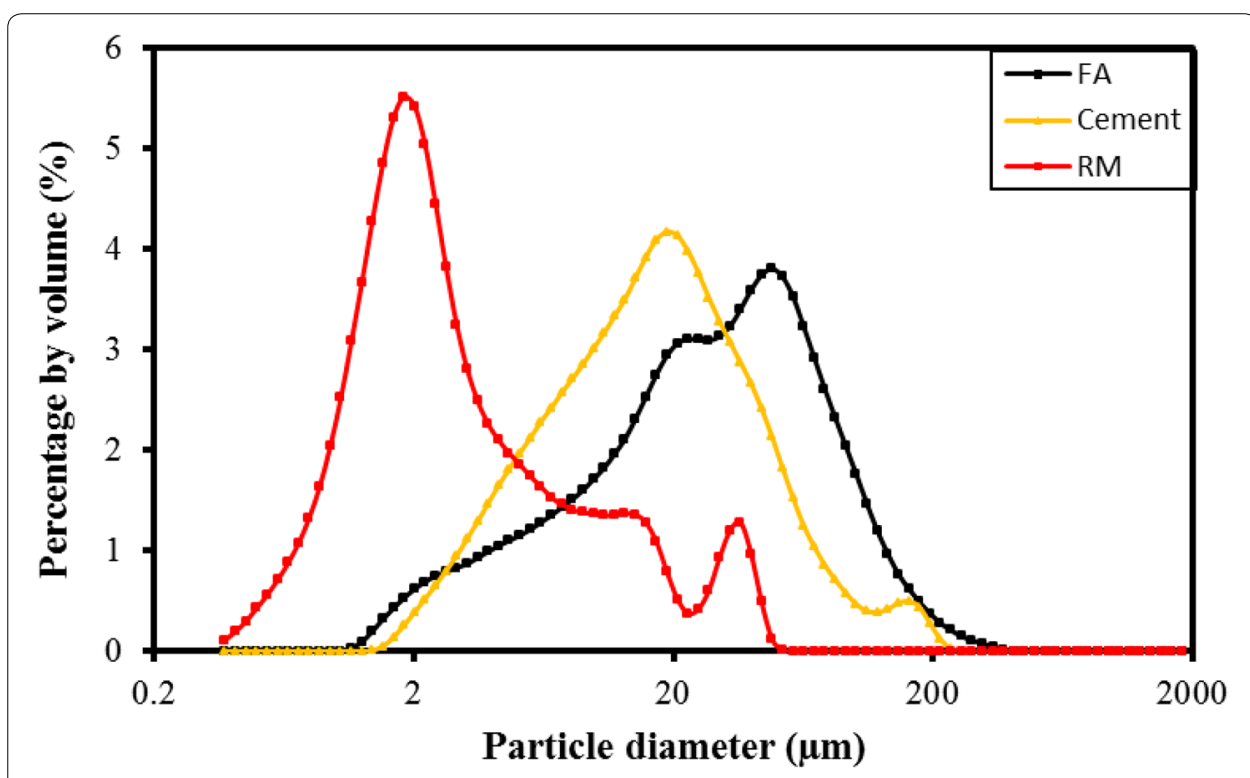

Fig. 2 Particle size distributions of fly ash, cement and RM

Figure 3 shows an X-ray diffractometer of ponded ash, fly ash, cement and RM. The XRD patterns are obtained with $\mathrm{Cu} K \alpha$ radiation with generator settings at $30 \mathrm{~mA}$ and $40 \mathrm{kV}$. It can be observed that the PA and FA mainly consisted of quartz and mullite and the characteristic peaks of PA were quite similar to those of FA. The XRD result of cement is well-known as shown in Fig. 3. In addition, it was also found in RM some mineral components such as quartz, gibbsite and some amount of hedenbergite, hematite.

\section{Mixture proportions and test procedures}

A control mixture was initially produced with ponded ash, Portland cement, Class F fly ash, and water. Subsequently, red mud was substituted for Portland cement in amounts of $5,10,15,20,25$, and $30 \%$ by weight. The proportions of various CLSM mixtures are 


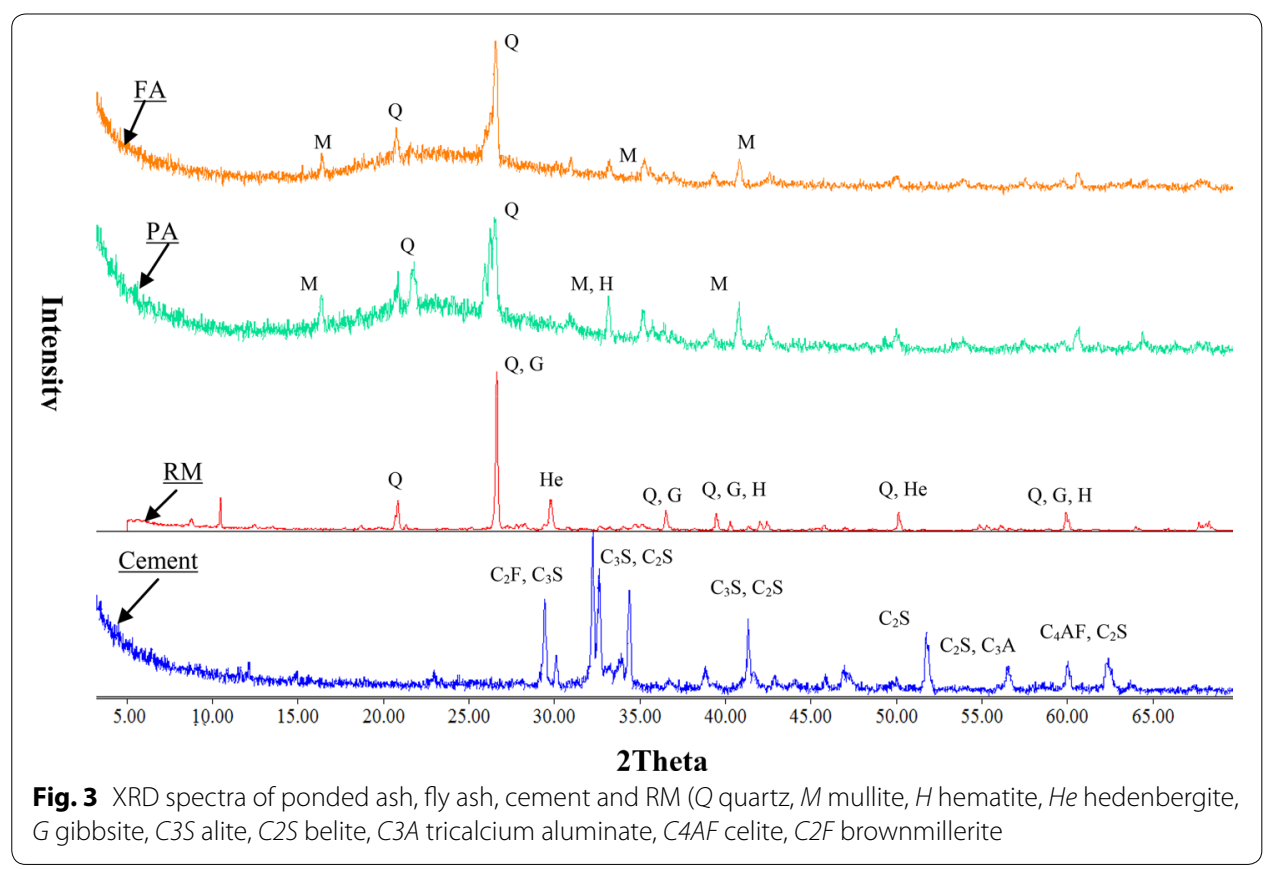

shown in Table 4. In the mix proportions, the label "RM" indicates the red mud and the numbers of " 5 ", " 10 ", " 15 ", " 20 ", " 25 ", and " 30 " signify the percentage of red mud replacement to cement.

The bleeding, flowability, fresh density, and setting time were tested immediately after mixing in accordance with applicable ASTM Standards (2004): C 232, D 6103, C 138, C 403, respectively. The CLSM mixtures were prepared as follows. Cement and red mud were firstly dry-mixed for $2 \mathrm{~min}$ and ponded ash and fly ash were then added and drymixed for $5 \mathrm{~min}$ for homogeneity in mixtures. Finally, the designed amount of water was added and mixed for at least $10 \mathrm{~min}$ by a laboratory mixer. Flowability is the property that governs the self-leveling ability of CLSM. In this study, flowability of CLSM was measured according to ASTM D 6103 with an open-end flow cylinder with $150 \mathrm{~mm}$ of length and $75 \mathrm{~mm}$ in diameter. The cylinder was initially placed on a levelled nonporous plate and then filled with fresh CLSM. The cylinder was lifted slowly within $5 \mathrm{~s}$ allowing

Table 4 Mix proportions of CLSM

\begin{tabular}{|c|c|c|c|c|c|c|c|c|c|}
\hline \multirow[t]{2}{*}{ Mix ID } & \multicolumn{2}{|c|}{$\begin{array}{l}\text { Weight proportion } \\
\text { of RM and cement (\%) }\end{array}$} & \multicolumn{5}{|c|}{ Unit weight $\left(\mathrm{kg} / \mathrm{m}^{3}\right)$} & \multirow{2}{*}{$\begin{array}{l}\text { Fresh } \\
\text { density } \\
\left(\mathrm{kg} / \mathrm{m}^{3}\right)\end{array}$} & \multirow[t]{2}{*}{$\begin{array}{l}\text { Cement } \\
\text { content \% }\end{array}$} \\
\hline & $\mathrm{RM}$ & Cement & $\mathrm{RM}$ & Cement & Fly ash & Ponded ash & Water & & \\
\hline $\begin{array}{l}\text { Control } \\
\text { mixture }\end{array}$ & 0 & 100 & 0 & 88 & 264 & 1005 & 483 & 1841 & 4.79 \\
\hline RM-5 & 5 & 95 & 4 & 84 & 264 & 1005 & 483 & 1841 & 4.55 \\
\hline RM-10 & 10 & 90 & 9 & 79 & 264 & 1005 & 483 & 1840 & 4.31 \\
\hline RM-15 & 15 & 85 & 13 & 75 & 264 & 1004 & 483 & 1840 & 4.07 \\
\hline RM-20 & 20 & 80 & 18 & 71 & 265 & 1005 & 483 & 1841 & 3.83 \\
\hline RM-25 & 25 & 75 & 22 & 66 & 264 & 1004 & 483 & 1839 & 3.59 \\
\hline RM-30 & 30 & 70 & 26 & 62 & 264 & 1004 & 483 & 1840 & 3.35 \\
\hline
\end{tabular}


the fresh CLSM mixture to spread freely onto the plate. The diameters of spread in two perpendicular directions were measured. The average diameter of spread represents the flowability of the mixture [42]. A flowability of $200-300 \mathrm{~mm}$ is suitable for high flowability in a CLSM mixture as stated in ACI 229R and it is considered flowable and acceptable for most applications. Bleeding is commonly used to quantify the degree of subsidence for CLSM and was measured in this study according to ASTM C 232. A $150 \times 150 \mathrm{~mm}$ cylinder mould was filled with fresh CLSM mixture and then covered with a plastic parafilm to prevent evaporation. The volume of bleed water which accumulated at the surface of the CLSM was recorded until two successive readings showed no further bleeding. The bleeding was expressed as a percentage with the volume of bleed water over the initial volume of CLSM mixture. CLSM was considered stable with bleeding less than $5 \%$ by volume at $2 \mathrm{~h}[9,45]$. The fresh density of CLSM was obtained by measuring the weight of the fresh CLSM mixture filled with a $100 \times 200 \mathrm{~mm}$ cylinder container. Initial setting time was performed by penetration resistance test according to ASTM C 403, as shown in Fig. 4. A container of $150 \mathrm{~mm}$ in diameter and $150 \mathrm{~mm}$ in depth was first filled with fresh CLSM mixture. Before starting the penetration test, bleed water was removed from the surface of the CLSM mixture by means of a pipet or suitable instrument. In this study, the needle with $16 \mathrm{~mm}^{2}$ in area was selected and then inserted into contact with the CLSM sample until the penetration reached a depth of $25 \mathrm{~mm}$. The time required to penetrate to the $25 \mathrm{~mm}$ depth should be $10 \pm 2 \mathrm{~s}$. The forces required to produce the $25 \mathrm{~mm}$ penetration was recorded at different time intervals. The penetration resistance was calculated by dividing the recorded force by the bearing area of the needle. The period of time from the initial contact of cement and water to the time of reaching a penetration resistance of $2.74 \mathrm{MPa}$ was chosen as the initial setting time.

Unconfined compressive strength test was further performed with $50 \times 100 \mathrm{~mm}$ cylindrical specimens moulded in plastic moulds and then stored under the curing storage

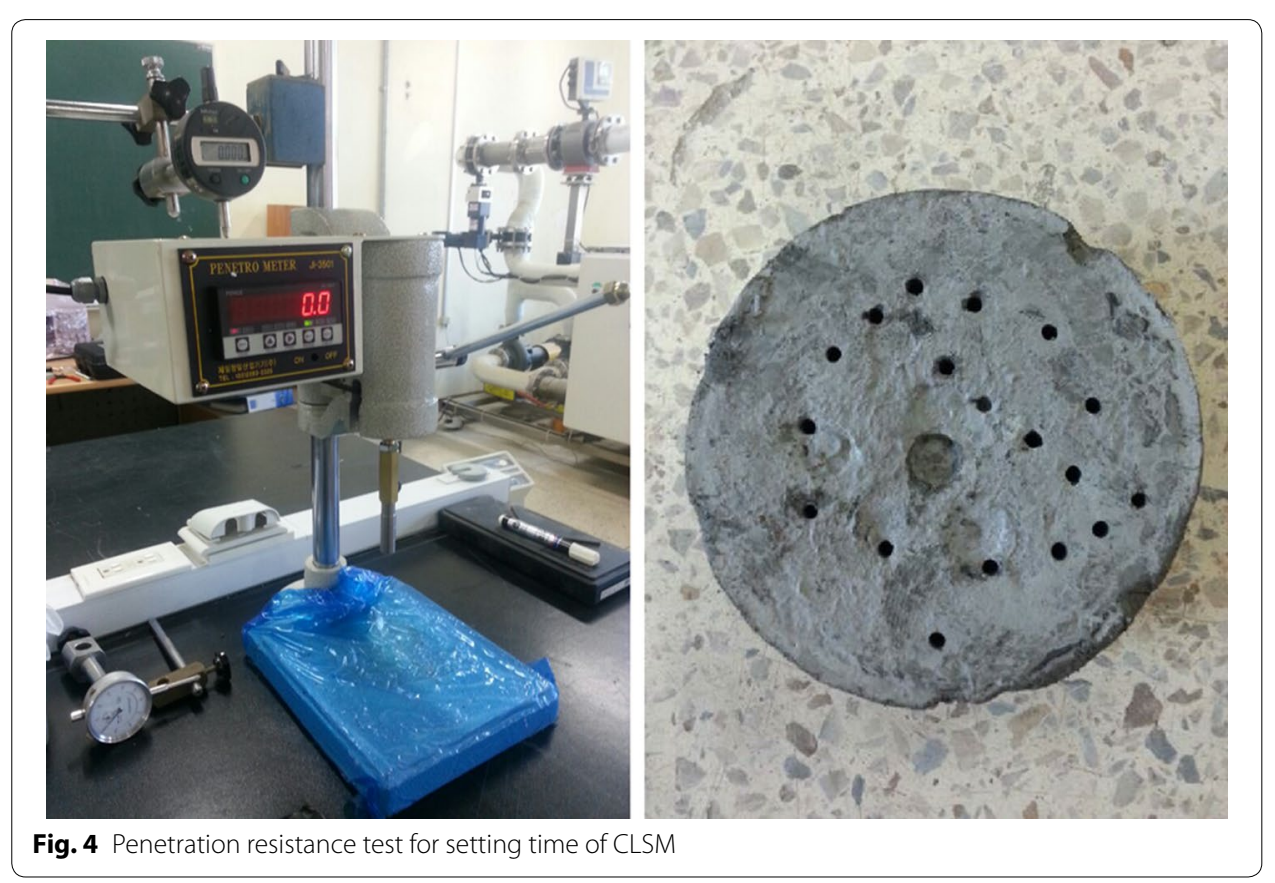


condition with a curing chamber that can maintain the temperature of $25{ }^{\circ} \mathrm{C}$ and $100 \%$ of relative humidity immediately adjacent to the cylinders until desirable testing times of 3, 7 and 28 days as presented in ASTM D 4832. The universal testing machine with loading rate $1.1 \mathrm{~mm} / \mathrm{min}$ was employed for the unconfined compressive strength test. Each strength test was carried out on three cylindrical specimens and then the average was recorded. The mix proportions were designed to satisfy the compressive strength requirement of less than $2.1 \mathrm{MPa}$ for future re-excavation (i.e., general fill), as reported in ACI 229R [2]. Finally, in order to verify the main environmental problems due to red mud (i.e., high $\mathrm{pH}$ value of this waste) incorporating in CLSM mixtures, the corrosivity was studied by measuring $\mathrm{pH}$ of bleed and leachate collected from CLSM to identify and evaluate whether a satisfactory corrosivity can be obtained with the proposed mixtures. Corrosivity is ability of materials that probably and potentially causes a hazard to human health or the environment to mobilize toxic metals if discharged into the environment. It can be a reason to corrode handling, storage, transportation, and management equipment, or to destroy human or animal issue in the event of inadvertent contact. Corrosion can occur when water or leachate water reacts with metal parts. Solid waste exhibits corrosivity if a representative sample of the waste has the property that is aqueous and has a $\mathrm{pH}$ less or equal to 2 or greater than or equal to $12.5[32,40]$.

\section{Results and discussion}

\section{Flowability}

The values of flowability for all CLSM mixtures are shown in Fig. 5. The flowability of control mixture showed a highest value of $300 \mathrm{~mm}$ and then follows were 270, 265, 260, 260, 245, $240 \mathrm{~mm}$ for mixtures of RM-5, RM-10, RM-15, RM-20, RM-25, and RM-30, respectively. In total, as expected for all CLSM mixtures, flowability ranged from 240 to $300 \mathrm{~mm}$ conforming to the performance requirements for general flowability grade for CLSM reported in ACI 229R [2]. In addition, it was found that the flowability was affected by the red mud content (i.e., the amount of red mud replacement to cement). In particular, as the amount of red mud replacement increased, the flowability of CLSM mixtures was slightly decreased as illustrated in Fig. 5 but still showed good flowability of higher than $200 \mathrm{~mm}$. This tendency is primarily due to a much larger in specific surface area of red mud $\left(\mathrm{Ss}_{\mathrm{RM}}=15.9 \mathrm{~m}^{2} / \mathrm{g}\right)$ than that of Portland cement $\left(\mathrm{Ss}_{\text {cement }}=1.22 \mathrm{~m}^{2} / \mathrm{g}\right)$. As the red mud content increased, the specific surface areas of mixtures became larger. Then, the amount of surface-adsorbed water was increased. In these cases, CLSM mixtures need more water demand to reach equilibrium workability. However, it is worth remembering that the amount of water in CLSM mixtures was fixed in this study. Therefore, flowability of CLSM was reduced. This observation is consistent with the previous researches of Kuo et al. [15]; Katz and Kovler [14].

\section{Bleeding}

Water used for flowability in excess of that needed for hydration is generally absorbed by the surrounding soil or released to the surface as bleed water [2]. Figure 6 shows the bleeding results of various CLSM mixtures with respect to time. The bleeding test was measured at $15,30,45,60,120,180,240,300$, and $360 \mathrm{~min}$. As a result, there was a huge difference in bleeding from control mixture (i.e., without using red mud) and 


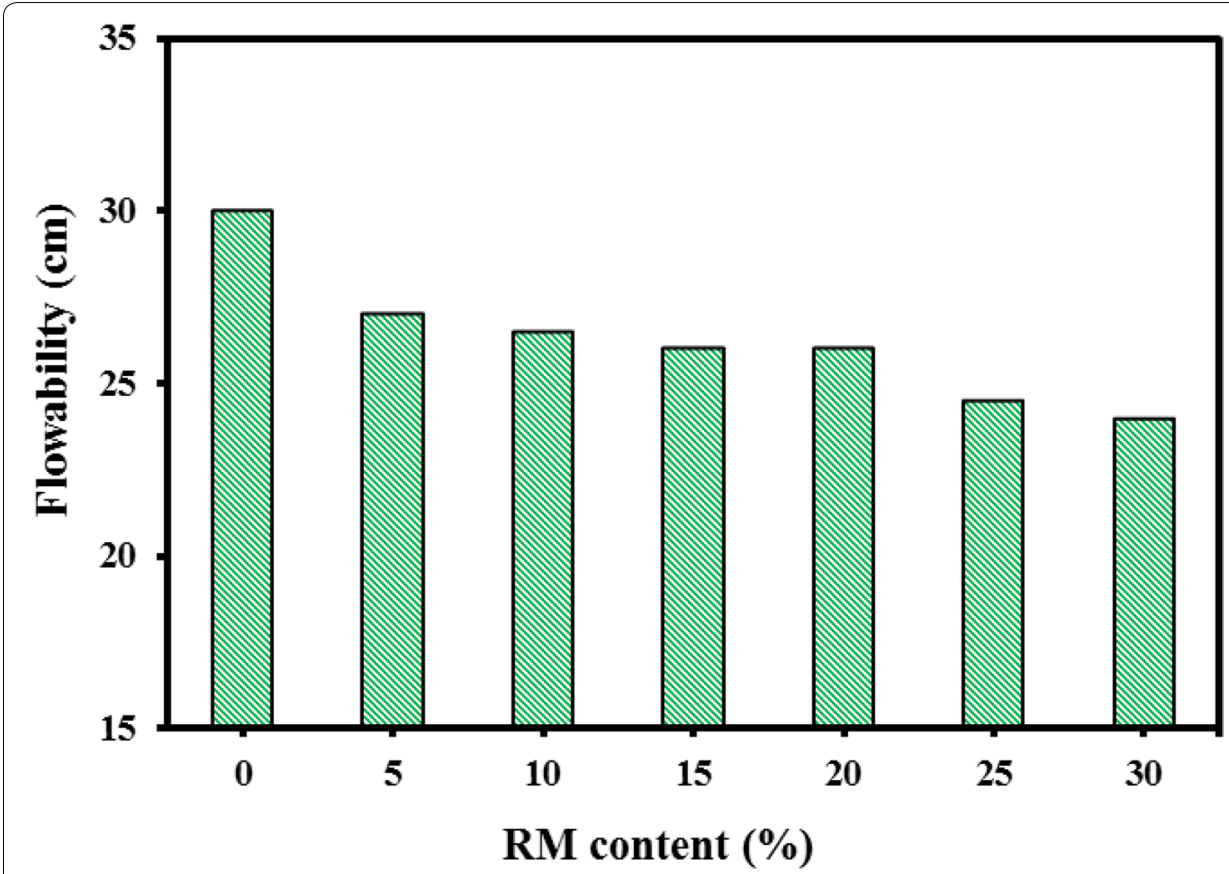

Fig. 5 Flowability of the CLSM mixtures with respect to red mud content

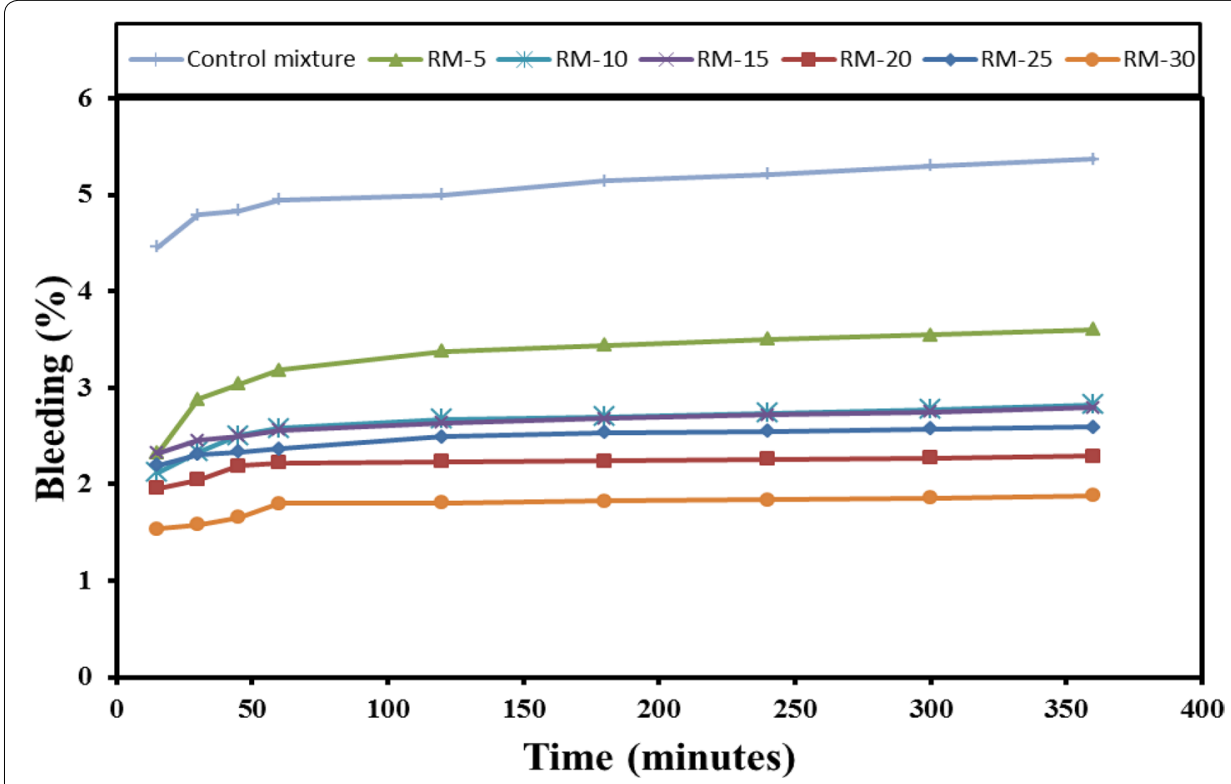

Fig. 6 Bleeding of the CLSM mixtures with respect to measuring time

others. Particularly, incorporating red mud in CLSM mixtures could lead to an effective improvement in the stability of mixtures throughout the decreases in bleeding. As mentioned before, CLSM is considered stable with bleeding less than $5 \%$ by volume at $2 \mathrm{~h}[9,45]$. Therefore, the bleed results of all prepared CLSM mixtures should be taken into account at $2 \mathrm{~h}$. The values of bleeding at $2 \mathrm{~h}$ for all CLSM mixtures are shown in Fig. 7. These values of control mixture, RM-5, RM-10, RM-15, RM-20, RM-25, 


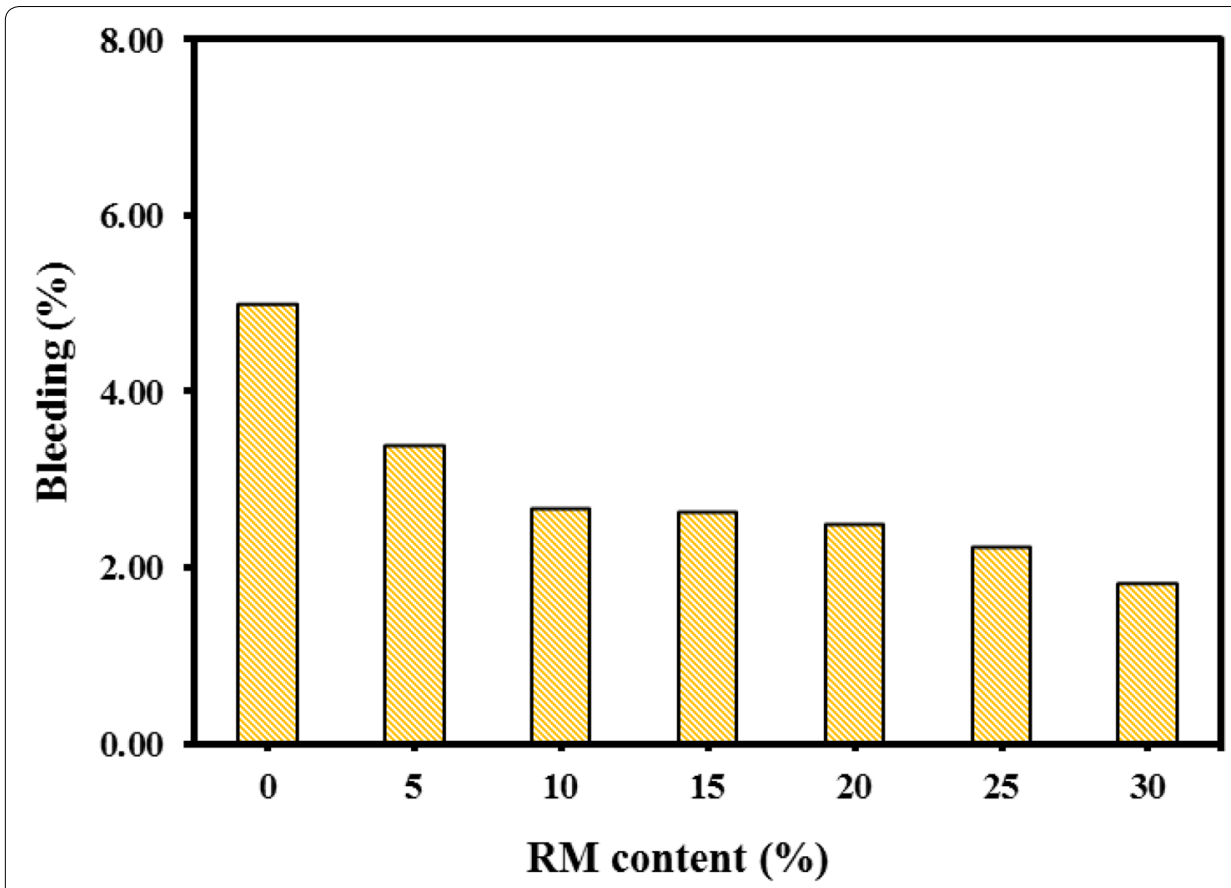

Fig. 7 Bleeding of the various CLSM mixtures at $2 \mathrm{~h}$

and RM-30 mixtures were 5, 3.38, 2.67, 2.64, 2.49, 2.23, and $1.81 \%$, respectively. Expectedly, the bleeding values of all prepared mixtures varied in the range of 1.81-5.00 \%, all of which conformed to the bleeding requirement of CLSM. For the present investigation, CLSM is considered stable with bleeding of all mixtures less than $5 \%$. The bleeding level of all prepared CLSM mixtures in this study is more stable than that of other mixtures also made with industrial wastes reported by Razak et al. [32] (1.2-7.2 \%), Tikalsky et al. [39] (0-8.73\%). More importantly, an increase in red mud content could lead a decrease in bleeding of CLSM in comparison with the control mixture. In particular, as the red mud content increased up to $30 \%$, the bleeding dramatically reduced to $1.81 \%$. This implies that CLSM is considered more stable at higher red mud content in mixtures. These observations suggest that red mud could become the particularly important material in improving the stability of CLSM mixtures. This effect might be explained by the plastic properties of red mud that could decrease in bleeding of mixtures since the excess amount of capillary water would be partially retained in the mixtures containing red mud. In addition, the much larger in the specific surface area of red mud than that of Portland cement might also be another reason explained for a decrease in bleeding of mixtures containing red mud. The replacement of red mud in mixtures could induce an increase in the amount of surface-adsorbed water and eventually make a decrease in bleeding due to the amount of water being fixed in this study.

\section{Initial setting time}

The initial setting time of CLSM mixtures is shown in Fig. 8. The initial setting times of control mixture, RM-5, RM-10, RM-15, RM-20, RM-25, RM-30 mixtures were 9.53, 9.76, $9.3,8.14,7.08,6.81$, and $6.44 \mathrm{~h}$, respectively. It was found in the range of 6.44-9.76 h, 


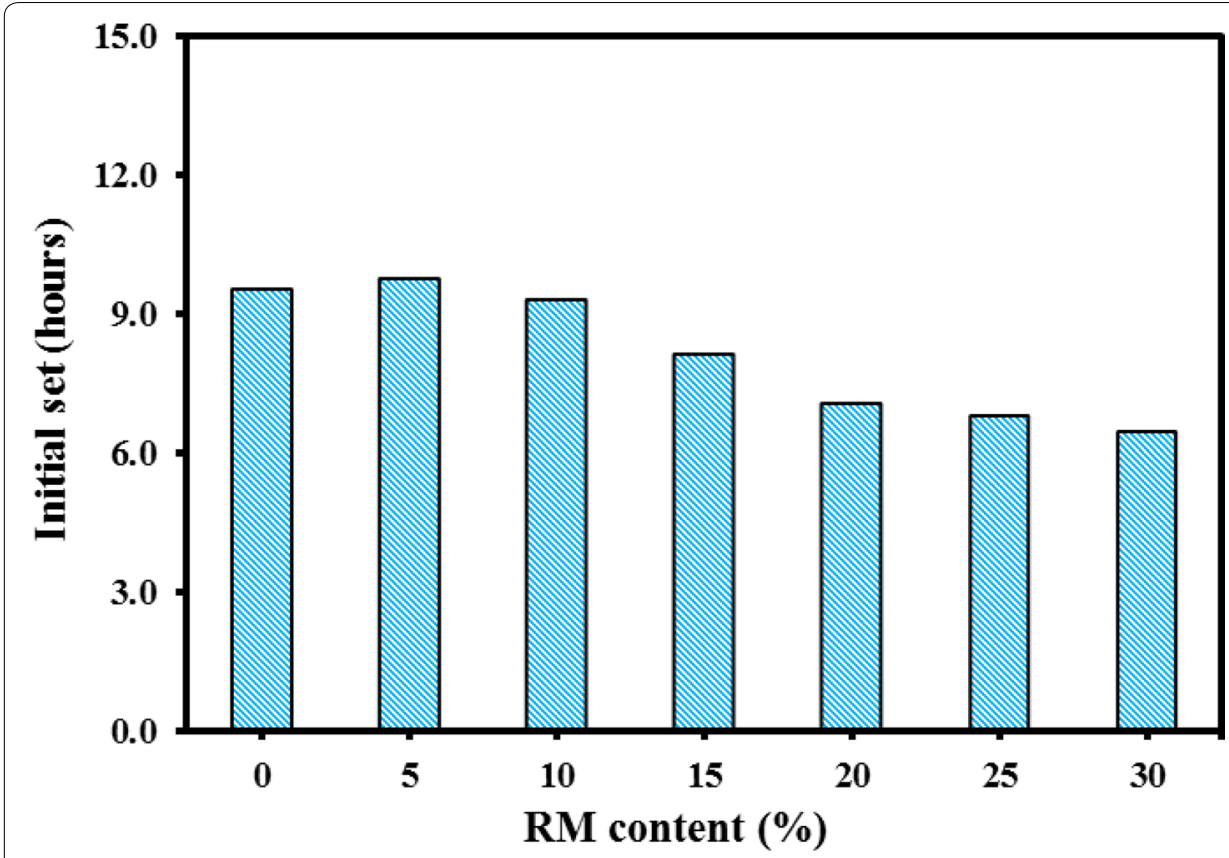

Fig. 8 Setting time of the various CLSM mixtures

below the maximum allowable limit of $36 \mathrm{~h}$ as required for general CLSM [15]. It is worth noting that the replacement of red mud tended to accelerate the setting process of CLSM mixtures. The initial setting time of control mixture was $9.53 \mathrm{~h}$. This time was slightly delayed as the red mud replacement increased from 0 to $5 \%$. However, when the replacement increased to $10,15,20,25,30 \%$, the initial setting time started to be gradually shortened by $2.4 \%$ (9.3 h), $14.6 \%$ (8.14 h), $25.7 \%$ (7.08 h), $28.5 \%$ (6.81 h), and $32.4 \%$ ( $6.44 \mathrm{~h})$, respectively. These finding implies that red mud could be used to accelerate the setting process of CLSM mixtures and might be explained by the redundant presence of $\mathrm{Al}_{2} \mathrm{O}_{3}(19.87 \%)$ and $\mathrm{Na}_{2} \mathrm{O}(14.92 \%)$ in red mud as shown in the chemical composition of red mud in Table 3. When mixed with water, the aluminium and sodium hydroxides are created and become good curing accelerators for CLSM mixtures. In other words, red mud releases $\mathrm{OH}^{-}$and generates a highly alkaline environment [6] favoured for the hydration reaction of Portland cement. In addition, as abovementioned, red mud particles could also be partially responsible for a water-retained process. Eventually, the available remained water used for combination with cement particles would be reduced and consumed rapidly due to the amount of water being fixed in this study. Therefore, the setting process was accelerated. This result is identical to that reported by Ribeiro et al. [33].

\section{Corrosivity}

The corrosivity of CLSM was measured as bleed and leachate collected from CLSM specimens and given in Table 5. The $\mathrm{pH}$ values of leachate and bleed of control mixture were 11.08 and 12.05 , respectively. These following values for mixtures RM-5, RM-10, RM-15, RM-20, RM-25, and RM-30 were 11.37 and 12.1, 11.41 and 12.1, 11.55 and 12.12, 11.51 and $12.16,11.53$ and $12.18,11.58$ and 12.25 , respectively. It indicated that bleed 
Table 5 pH values of various CLSM

\begin{tabular}{llll}
\hline Mix ID & Bleeding (\%) & pH & Leachate \\
\cline { 4 - 4 } & & Bleed & 11.08 \\
\hline Control mixture & 5.00 & 12.05 & 11.37 \\
RM-5 & 3.38 & 12.1 & 11.41 \\
RM-10 & 2.67 & 12.1 & 11.55 \\
RM-15 & 2.64 & 12.12 & 11.51 \\
RM-20 & 2.49 & 12.16 & 11.53 \\
RM-25 & 2.23 & 12.18 & 11.58 \\
RM-30 & 1.81 & 12.25 & \\
\hline
\end{tabular}

and leachate of all CLSM mixtures were alkaline, ranging from 12.05-12.25 and 11.0811.58, primarily due to the hydroxide released from red mud itself (i.e., the presence of aluminium and sodium hydroxides in red mud) as well as the hydration process. However, the range was neither less than 2.5 nor more than 12.5. Therefore, the CLSM possessed sufficient resistance to corrosivity [32, 40]. In addition, it is exhibited from Table 5 that the $\mathrm{pH}$ of bleed was higher than that of leachate for all proposed CLSM mixtures. It is identical to the previous results in the study by Razak et al. [32]. Furthermore, it was found that these $\mathrm{pH}$ values increased in both of bleed and leachate with an increase of red mud replacement probably due to an increase in amount of $\mathrm{OH}^{-}$released from aluminium and sodium hydroxides in red mud.

\section{Compressive strength}

The most important hardened property of CLSM is its strength measured as unconfined compressive strength (UCS). Figure 9 shows the unconfined compressive strengths in

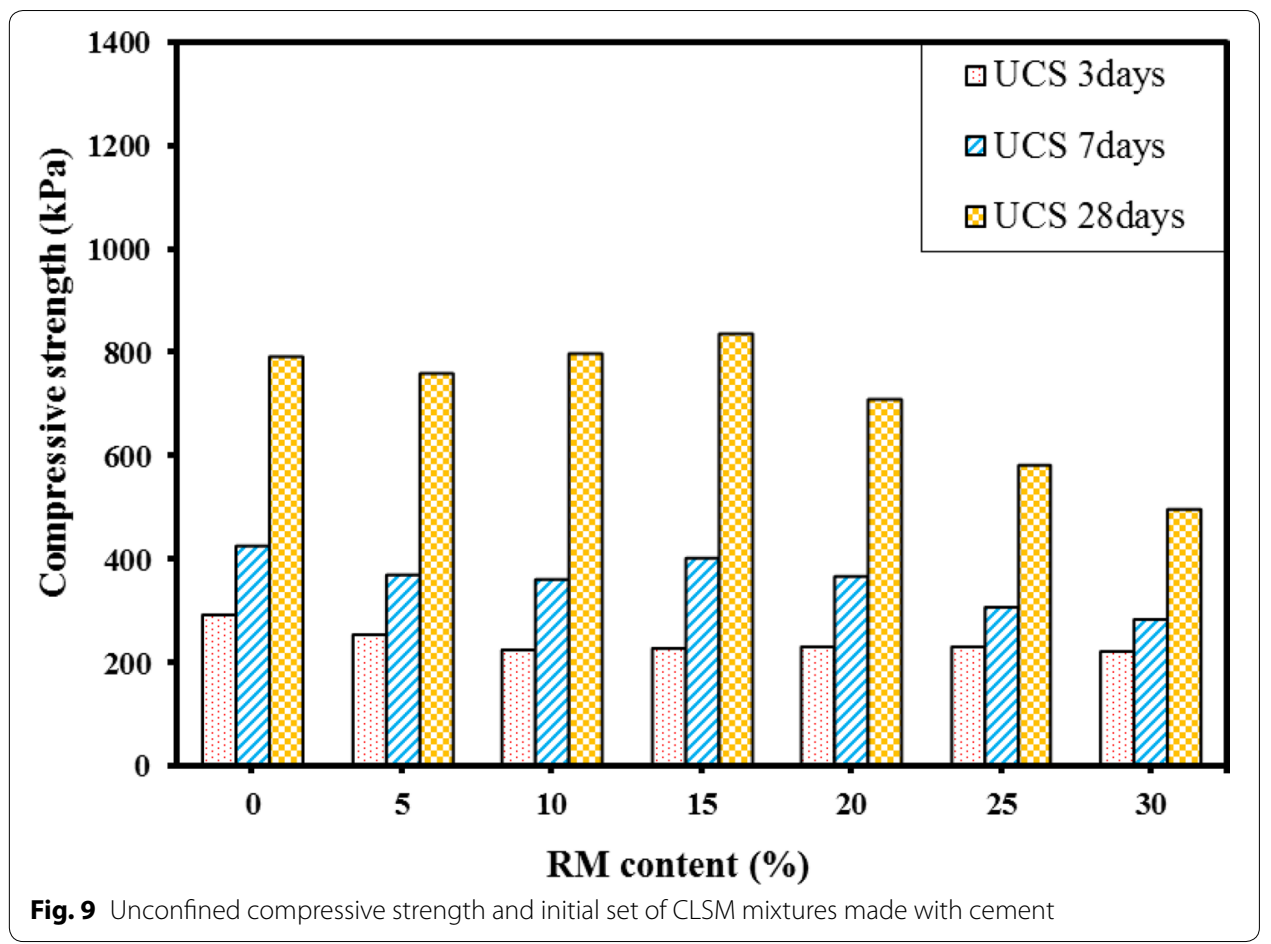


average for various CLSM mixtures in experimental program. There were increments in compressive strength of all CLSM mixtures due to the hydration process of cementitious materials which gradually completed with curing ages. The 3-day strength and 7-day strength varied in ranges of $0.26-0.30$ and $0.29-0.43 \mathrm{MPa}$, respectively. At the ages of 3 and 7 days, the compressive strength slightly changed with a corresponding increase in the red mud content. In particular, the 3-day strength was found the highest value of $0.296 \mathrm{MPa}$ (Control mixture) and follows were $0.257 \mathrm{MPa}$ (RM-5), 0.229 MPa (RM10), 0.231 MPa (RM-15), 0.232 MPa (RM-20), 0.233(RM-25), and 0.226 MPa (RM-30). The control mixture still showed the highest strength of $0.43 \mathrm{MPA}$ after 7 days curing. The strengths of RM-5, RM-10, RM-15, RM-20, RM-25, and RM-30 mixtures were 0.43 , $0.38,0.36,0.4,0.37,0.31$, and $0.29 \mathrm{MPa}$, respectively. At the age of 28 days, the strength of all proposed mixtures ranged from 0.50 to $0.84 \mathrm{MPa}$, conforming to the strength requirement of re-excavation despite the small amount of cement used (i.e., smaller than $4.79 \%)$. In addition, it is interesting to discover that the highest compressive strength of 28 days at the red mud replacement was $15 \%$, greater than that of the control mixture. The strength of control mixture was $0.79 \mathrm{MPa}$ and it increased up to $0.84 \mathrm{MPa}$ when the red mud content increased as $15 \%$. In other words, comparing to the control mixture, RM-15 mixture gained $6.3 \%$ in strength. It is likely to be due to the redundant presence of $\mathrm{Al}_{2} \mathrm{O}_{3}(19.87 \%)$ and $\mathrm{Na}_{2} \mathrm{O}(14.92 \%)$ and $\mathrm{CaO}(7.1 \%)$ in red mud. Calcium hydroxide released from red mud and Calcium hydroxide produced from hydration reaction of Portland cement, could react with the alumina left in red mud to produce calcium aluminates ( $\mathrm{CA}$ and possibly $\mathrm{C}_{3} \mathrm{~A}_{5}$ ). These also hydrate to produce cementitious compounds in reactions which are fairly well known from the fact that they are responsible for strength of mixtures with high alumina content in a highly alkaline environment [29, 33]. Furthermore, an increase in amount of hydroxide ions $\mathrm{OH}^{-}$might be another reason explained for a gain in strength. These $\mathrm{OH}^{-}$ions hydrolyzed on the surface of ponded ash or fly ash known as pozzolanic materials. Then, the $\mathrm{Si}, \mathrm{Al}$, and $\mathrm{Ca}$ species were dissolved to form $\mathrm{C}-\mathrm{S}-\mathrm{H}$ gel through polymerization resulting in a higher compressive strength of CLSM $[12,18]$. However, when the red mud replacement exceeded $15 \%$, the compressive strength started to be decreased dramatically. It dropped to $0.5 \mathrm{MPa}$ as the red mud replacement was up to $30 \%$ probably due to the lack of cement content in those CLSM mixtures. Therefore, the red mud content of $15 \%$ is considered as an optimum percentage to substitute Portland cement in this study. This finding is clearly demonstrated throughout in Fig. 10, which is built up to exhibit the strength increment slopes with respect to the red mud contents. Herein, the angular coefficients of strength trendlines of various CLSM mixtures with respect to curing time are signified the strength increment slopes of the prepared CLSM mixtures. The strength increment slopes of all mixtures with their R-squared values are summarized in Table 6. Therefore, it can thus be stated that red mud could be feasible and potential in use as a partial replacement to Portland cement in CLSM production with the optimum red mud content of $15 \%$.

\section{Conclusions}

The laboratory tests were conducted to evaluate the feasibility of incorporating red mud as a partial replacement for Portland cement into a controlled low-strength material made by industrial by-products (e.g., ponded ash and fly ash) generated from coal 
combustion process of thermal power plants in Honam area and those lead to the following conclusions:

1. Flowability of prepared mixtures decreased with a corresponding increase in the red mud content primarily due to a much larger in specific surface area of red mud than that of Portland cement. However, all prepared CLSM mixtures still showed the flowability of higher than $200 \mathrm{~mm}$, the performance requirement for good flowability grade for CLSM reported in ACI 229R.

2. The bleeding values of all prepared mixtures varied in the range of $1.81-5.00 \%$ at $2 \mathrm{~h}$, all of which conformed to the bleeding requirement of CLSM. In addition, the bleeding was found to be significantly decreased with an increase in red mud content in CLSM mixtures mainly due to the plastic properties of red mud that might keep

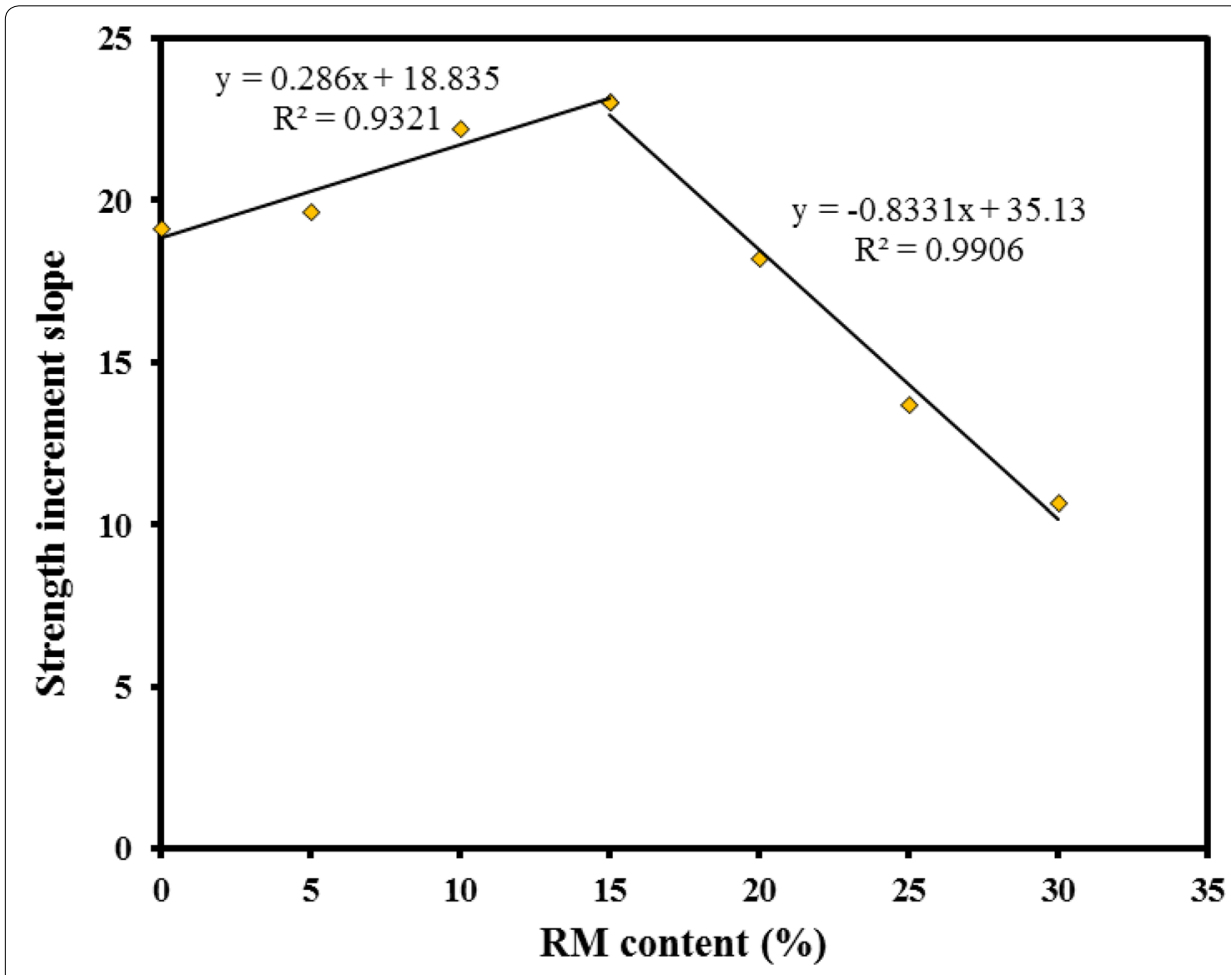

Fig. 10 Strength increment slopes of CLSM mixtures with respect to RM content

Table 6 Strength increment slopes of various CLSM mixtures

\begin{tabular}{llll}
\hline Mix ID & RM content (\%) & Strength increment slopes & R-squared value \\
\hline RM-5 & 5 & 19.618 & 0.9947 \\
RM-10 & 10 & 22.186 & 0.994 \\
RM-15 & 15 & 23.013 & 0.9831 \\
RM-20 & 20 & 18.204 & 0.9834 \\
RM-25 & 25 & 13.696 & 0.9958 \\
RM-30 & 30 & 10.631 & 0.9951 \\
\hline
\end{tabular}


the excess amount of capillary water in the mixtures containing red mud. In addition, the much larger in the specific surface area of red mud than that of Portland cement might also be another reason explained for a decrease in bleeding of mixtures. Therefore, red mud can become the particularly important material in improving the stability (bleeding level) of proposed CLSM mixtures.

3. Initial setting time was found in the range of 6.44-9.76 h, below the maximum allowable limit as required for general CLSM. It is worth noting that the replacement of red mud tended to accelerate the setting process of CLSM mixtures due to the redundant presence of $\mathrm{Al}_{2} \mathrm{O}_{3}$ and $\mathrm{Na}_{2} \mathrm{O}$ in red mud that might act as an accelerator by providing a highly alkaline environment favored for the hydration reaction in CLSM mixtures. In other words, red mud can be used to improve the setting process of CLSM.

4. In this study, all prepared CLSM mixtures did not possess corrosivity from the aspect of $\mathrm{pH}$, within the limiting values of both bleed and leachate, neither less than 2.5 nor more than 12.5 .

5. All of the CLSM mixtures exhibited a gain in unconfined compressive strength with curing ages. The compressive strength of all proposed mixtures measured was conformed to the strength requirement of re-excavation despite the decrease amount of cement.

6. In overall, red mud could be feasible and potential in use as a partial replacement to Portland cement in CLSM production.

\section{Authors' contributions}

YSK gave the ideal of this paper. He did manage the test procedures. Then he participated in the sequence alignment and drafted the manuscript. TMD carried out the est program and then participated and drafted the manuscript. Both authors read and approved the final manuscript.

\section{Acknowledgements}

This research was supported by a grant (No 16-RDRP-B076564-03) from Regional Development Research Program funded by Ministry of Land, Infrastructure and Transport of Korean government.

\section{Competing interests}

The authors declare that they have no competing interests.

Received: 18 March 2016 Accepted: 25 April 2016

Published online: 05 May 2016

\section{References}

1. Achtemichuk S, Hubbard J, Sluce R, Shehata MH (2009) The utilization of recycled concrete aggregate to produce controlled low-strength materials without using Portland cement. Cement Concr Compos 31(8):564-569

2. ACl Committee 229 (1999) Controlled low strength materials (ACI 229R-99). American Concrete Institute, Farmington Hill

3. Amritphale SS, Patel M (1987) Utilisation of red mud, fly ash for manufacturing bricks with pyrophyllite. Silicates Ind 52(3-4):31-35

4. Bhat ST, Lovell CW (1997) Flowable fill using waste foundry sand: a substitute for compacted or stabilized soil. In: Proceedings: testing soil mixed with waste or recycled materials (ASTM STP 1275), American Society for Testing and Materials, Conshohocken. p 26-41

5. Butalia TS, Wolfe WE, Lee JW (2001) Evaluation of a dry FGD material as a flowable fill. Fuel 80(6):845-850

6. Chandra S (1997) Waste materials used in concrete manufacturing. Noyes Publications, Westwood

7. Dimas DD, Giannopoulou I, Panias D (2009) Utilization of alumina red mud for synthesis of inorganic polymeric materials. Miner Process Extr Metall Rev 30(3):211-239

8. Dockter B (1998) Comparison of dry scrubber and class C fly ash in CLSM application. In: Proceedings the design and application of controlled low strength materials (flowable fill) (ASTM STP 1331). American Society for Testing and Materials, West Conshohocken, p 13-26

9. Gabr MA, Bowders JJ (2002) Controlled low-strength material using fly ash and AMD sludge. J Hazard Mater 76(2):251-263 
10. Giannopoulou I, Dimas D, Maragkos I, Panias D (2009) Utilization of metallurgical solid by-products for the development of inorganic polymeric construction materials. Global NEST J 11(2):127-136

11. Hind AR, Bhargava SK, Grocott SC (1999) "The surface chemistry of Bayer process solids", a review. Colloids Surf A Physicochem Eng Asp 146(1-3):359-374

12. van Jaarsveld JGS, van Deventer JSJ, Lukey GC (2003) The characterisation of source materials in fly ash-based geopolymers. Mater Lett 57(7):1272-1280

13. Kalkan E (2006) Utilization of red mud as a stabilization material for the preparation of clay liners. Eng Geol 87(3-4):220-229

14. Katz A, Kovler K (2004) Utilization of industrial by-products for the production of controlled low strength materials (CLSM). Waste Manag 24(5):501-512

15. Kuo WT, Wang HY, Shu CY, Su DS (2013) Engineering properties of controlled low-strength materials containing waste oyster shells. Constr Build Mater 46:128-133

16. Lachemi M, Hossain KMA, Shehata M, Thaha W (2008) Controlled low strength materials incorporating cement kiln dust from various sources. Cem Concr Compos. 30(5):381-392

17. Lachemi M, Sahmaran M, Hossain KMA, Lotfy A, Shehata M (2010) Properties of controlled low-strength materials incorporating cement kiln dust and slag. Cem Concr Compos. 32(8):623-629

18. Lee NK, Kim HK, Park IS, Lee HK (2013) Alkali-activated, cementless, controlled low-strength materials (CLSM) utilizing industrial by-products. Constr Build Master 49:738-746

19. Lim KH, Shon BH (2015) Metal components ( $\mathrm{Fe}, \mathrm{Al}$, and Ti) recovery from red mud by sulfuric acid leaching assisted with ultrasonic waves. Int J Emerg Technol Adv Eng 5(2):25-32

20. Muhmood L, Vitta S, Venkateswaran D (2009) Cementitious and pozzolanic behavior of electric arc furnace steel slags. Cem Concr Res 39(2):102-109

21. Naganathan S, Razak HA, Hamid SNA (2010) Effect of kaolin addition on the performance of controlled low-strength material using industrial waste incineration bottom ash. Waste Manage Res 28(9):848-860

22. Naganathan S, Razak HA, Hamid SNA (2012) Properties of controlled low-strength material made using industrial waste incineration bottom ash and quarry dust. Mater Des 33:56-63

23. Naik TR, Kraus RN, Sturzl RF, Ramme BW (1998) "Design and testing controlled low-strength materials (CLSM) using clean coal ash", the design and application of controlled low-strength materials, ASTM STP 1331. American Society for Testing and Materials, West Conshohocken, pp 27-42

24. Nataraja MC, Nalanda Y (2008) Performance of industrial by-products in controlled low-strength materials (CLSM). Waste Manag 28(7):1168-1181

25. Ohlheiser TR (1998) Utilization of recycled glass as aggregate in CLSM. In: Proceedings the design and application of controlled low strength materials (flowable fill), (ASTM STP 1331). American Society for Testing and Materials, West Conshohocken, p 60-64

26. Pierce CE, Blackwell MC (2003) Potential of scrap tire rubber as lightweight aggregate in flowable fill. Waste Manag 23(3):197-208

27. Pierce CE, Gassman SL, Richards TM (2002) Long-term strength development of controlled low-strength material. ACl Mater J 99(2):157-164

28. Pierce CE, Tripathi H, Brown TW (2003) Cement kiln dust in controlled low strength materials. ACI Mater J 100(6):455-462

29. Pinnock WR, Gordon JN (1992) Assessment of strength development in Bayer process residues. J Mater Sci 27(3):692-696

30. Qiu XR, Qi YY (2011) Reasonable utilization of red mud in the cement industry. Cem Technol 6:103-105

31. Razak HA, Naganathan S, Hamid SNA (2010) Controlled low-strength material using industrial waste incineration bottom ash and refined kaolin. Arabian J Sci Eng 35(2B):53-67

32. Razak HA, Naganathan S, Hamid SNA (2009) Performance appraisal of industrial waste incineration bottom ash as controlled low-strength material. J Hazard Mater 172(2):862-867

33. Ribeiro DV, Labrincha JA, Morelli MR (2011) Potential use of natural red mud as pozzolan for Portland cement. Mat Res 14(1):60-66

34. Sglavo VM, Maurina S, Conci A, Salviati A, Carturan G (2000) "Bauxite red mud in the ceramic industry", Part 2: production of clay based ceramics. J Eur Ceram Soc 20(3):245-252

35. Sheen YN, Zhang LH, Le DH (2013) Engineering properties of soil-based controlled low-strength materials as slag partially substitutes to Portland cement. Constr Build Master 48:822-829

36. Siddique R, Noumowe A (2008) Utilization of spent foundry sand in controlled low-strength materials and concrete. Resour Conserv Recyl 53(1-2):27-35

37. Siddique R (2009) Utilization of waste materials and by-products in producing controlled low-strength materials. Resour Conserv Recycl 54(1):1-8

38. Singh M, Upadhayay SN, Prasad PM (1997) Preparation of iron rich cement from red mud. Cem Concr Res 27(7):1037-1046

39. Tikalsky P, Gaffney M, Regan R (2000) Properties of controlled low strength material containing foundry sand. ACl Mater J 97(6):698-702

40. Tikalsky PJ, Bahia HU, Deng A, Snyder T (2004), "Excess foundry sand characterization and experimental investigation in controlled low-strength material and hot-mixing asphalt", Final report, U.S. department of energy, Contract No. DE-FC36- $011 \mathrm{D} 13794$

41. Trejo D, Folliard KJ, Du L (2004), "Sustainable development using controlled low strength material", In: Proceedings of the international workshop on sustainable development and concrete technology. Beijing (China), pp 231-250

42. Tripathi H, Pierce CE, Gassman SL, Brown TW (2004) Method for field and laboratory measurement of flowability antd setting time of controlled low strength materials. J ASTM Int 1(6):74-88

43. Tsakiridis PE, Agatzini-Leonardou S, Oustadakis P (2004) Red mud addition in the raw meal for the production of Portland cement clinker. J Hazard Mater 116(1-2):103-110 
44. Yalcin N, Sevinc V (2000) Utilization of bauxite waste in ceramic glazes. Ceram Int 26(5):485-493

45. Yan DYS, Tang IY, Lo IMC (2014) Development of controlled low-strength material derived from beneficial reuse of bottom ash and sediment for green construction. Constr Build Mater 64:201-207

46. Yang JK, Chen F, Xiao B, Liu W (2006) Engineering application of basic level materials of red mud high level pavement. China Munic Eng 5:7-9

Submit your manuscript to a SpringerOpen ${ }^{\circ}$ journal and benefit from:

- Convenient online submission

- Rigorous peer review

Immediate publication on acceptance

- Open access: articles freely available online

- High visibility within the field

- Retaining the copyright to your article

Submit your next manuscript at $\boldsymbol{\nabla}$ springeropen.com 